\title{
FORECASTING THE POTENTIAL \\ OF THE ECONOMIC SYSTEM ON THE BASIS \\ OF THE EXOGENIC GROWTH MODEL
}

\section{ПРОГНОЗУВАННЯ ПОТЕНЦІАЛУ \\ ЕКОНОМІЧНОЇ СИСТЕМИ НА ПІДГРУНТІ \\ МОДЕЛІ ЕКЗОГЕННОГО ЗРОСТАННЯ}

\section{Sergiy Poznyak ${ }^{1}$ \\ Yurii Kolyada ${ }^{2}$}

DOI: https://doi.org/10.30525/978-9934-26-021-6-20

Abstract. The paper considers models of economic growth and the possibility of modifying a suitable model to find the potential for economic growth for the econo-my of society. The world global economy is studied, presented in terms of societies of the world, in monetary terms and the growth potential of gross domestic product in relation to capital, labor, technological progress, population and other macroeconomic indicators that affect it. Theoretical and methodological significance lies in the description of a fundamentally new method of modeling, which can be used to assess the potential of economic development, proving the dynamics of the coefficients of elasticity of production factors, and proving the hypothesis of declining economic growth. The developed model effectively estimates the potential for economic growth for any country and can be used as a basis for forecasting indicators of potential capital intensity of production and potential gross domestic product. Regarding the practical significance of the obtained results, it should be noted that all changes and numerical values are supported by real data and are a consequence of economic, political or social phenomena in the economy of the country under consideration. In the further research it is possible to develop this model, adding to it new variables which influence economic growth, to update methodology

\footnotetext{
${ }^{1}$ Undergraduate, Vadym Hetman Kyiv National University of Economics, Ukraine

${ }^{2}$ Doctor of Economics, Professor of the Department

of Economic and Mathematical Modeling,

Vadym Hetman Kyiv National University of Economics, Ukraine
} 
of finding of coefficients as a result of actions of economic agents, instead of only their exogenous influence on economy. The work has three main sections. The first section contains theoretical aspects of estimating the evolutionary economy in the one-dimensional case, it describes the basic theoretical information about the Solow model and other neoclassical and endogenous models of economic growth. The second section describes the possibilities of the Solow model for estimating economic growth potential and theoretical aspects and derives the mathematical basis for estimating economic growth potential. Also in this section describes the implementation of the mathematical base. The third section comments on the results of modeling, based on which detailed conclusions are formed, which summarize the economic, mathematical, analytical and technical work. The simulation results well illustrate the degree of use of economic potential, as well as the impact of capital, technological progress, investment, natural population movement on the efficiency of the economy in terms of many countries. The developed software (as a product of the digital economy) can be used to further improve the model, taking into account more factors.

\section{1. Ветуп}

В економіці будь-якої країни постійно відбуваються кількісні та якісні зміни в усіх іiї галузях. Основним показником кількісних та якісних змін в еко-номіці є валовий внутрішній продукт. Тож, коли в процесі виробництва відбу-вається збільшення обсягу та/чи якості ВВП, то здійснюється економічне зростання. Економічне зростання є однією 3 найважливіших проблем сучасного суспільства, яка є об'єктом дослідження багатьох сучасних економістів. Темп економічного зростання визначає розвиток країни, іiі політичне становище, авторитет на міжнародній арені та майбутні перспективи. Економічне зростання є найважливішою макроекономічною категорією, яка визначає здатність економіки до нарощення виробництва та спроможність до забезпечення зростаючих потреб населення країни. Особливо значущою дана проблема є для країн середнього рівня розвитку, до яких входить і Україна, та країн, що розвиваються, адже необхідно правильно поєднати фактори економічного зростання, а саме: природні ресурси, трудові ресурси, капітал та технології. Лише вірне поєднання у правильних пропорціях даних факторів дозволить країні досягнути певного рівня розвитку. 
У роботі проаналізовано більшість відомих моделей економічного зрос-тання, як неокласичних, так і ендогенних, визначено їх переваги та недоліки. Проблема визначення економічного зростання, зустрічалася ще в роботах неокейнсіанців, але першою знаковою роботою у напрямі оцінювання економічного зростання є стаття Роберта Солоу, який розглядав економічне зростання у розрізі двох основних виробничих ресурсів: капіталу та праці. Після нього модель доповнювалася новими змінними та новими підходами до визначення економічного росту, але все ще базою була саме модель Солоу, яку ще називають ортодоксальною. Останнім часом значних успіхів у розвитку розділі економічного зростання досягли П. Ромер, з його моделлю ендогенного економічного зростання на базі нового підходу до визначення технологічного прогресу, Ф. Агійон та П. Хоувіт, які $є$ авторами моделі економічного зростання 3 ендогенним технологічним прогресом на основі конкуренції.

Метою дослідження є розгляд моделей економічного зростання та модифікація підходящої моделі для знаходження потенціалу економічного росту для економіки суспільства країни. Також, одними із завдань $€$ : виведення математичної бази для оцінки потенціалу економічного зростання, аналітика макроекономічної ситуації та прогнозування за модифікованою моделлю, висування та підтвердження гіпотез на основі математичної бази.

Основою дослідження потенціалу економічного зростання $є$ ортодоксальна модель Солоу, яка модифікована таким чином, щоб відповідала предмету дослідження. Для знаходження коефіцієнтів моделі економічного зростання Солоу використовувалась логарифмічна форма рівняння Кобба-Дугласа, яке відображає мультиплікативну двофакторну виробничу функцію економіки. Для прогнозування на основі реальних даних використано мультиплікативну модель Хольта-Вінтерса, яка дозволяє максимізувати адекватність отриманих даних, оскільки включає у себе циклічність, лінійних тренд та експоненціальний згладжений ряд. Для кластеризації результатів дослідження використано карту Кохонена, яка працює на основі нейронних мереж, даний метод є більш цікавим за звичайну кластеризацію, оскільки використовує адаптивні методи машинного навчання. 


\section{2. Теоретичні аспекти оцінювання економічного потенціалу}

Розвиток економіки є основним інструментом покращення умов життя населення для кожної країни світу. Ефективне економічний розвиток впливає на стабільність політичного режиму, на задоволеність громадян, які проживають у тій чи іншій країні, на вплив держави на міжнародній арені тощо. Економічний розвиток вивчає теорія економічного зростання.

Теорія економічного зростання є однією з найважливіших та найскладніших частин економіки, як науки. Даний розділ економічної науки досліджує показники економічного зростання та їх природу. До таких показників зазвичай належать темп економічного зростання та внутрішній валовий продукт (ВВП). В умовах глобалізації економіки саме темп економічного зростання та обсяги створеного валового продукту визначають вплив та положення країни серед інших країн.

Основоположником теорії економічного зростання $є$ Роберт Мертон Солоу, який видав дві головні свої наукові праці «Вклад в теорію росту» [1] 1956 року та «Технічні зміни та агрегована виробнича функція» [2] 1957 року. На основі двох даних статей і була побудована неокласична модель економічного зростання Р. Солоу, за яку автор у 1987 році отримав Нобелівську премію з економіки за вклад в теорію економічного росту.

Модель економічного зростання Солоу є першою з неокласичних моделей подібного роду. До цього економічне зростання описували кейнсіанські моделі, які накладали ряд обмежень і не могли в такій точності описати процеси економічного розвитку, як це можна зробити за допомогою неокласичних моделей.

Екзогенна модель економічного розвитку має ряд передумов:

- На відміну від неокейнсіанських моделей для моделі Солоу було обрано виробничу функцію Кобба-Дугласа, яка складається з двох основних виробничих факторів: капіталу та праці, які є взаємозамінними. Формула рівняння наступна:

$$
Q=A K^{\alpha} L^{\beta},
$$

де Q - обсяг виробництва, або ВВП, К - обсяг капітальних ресурсів, $\mathrm{L}$ - кількість праці, $\alpha$ та $\beta$ є коефіцієнтами еластичності зміни капіталу та праці відповідно, А відповідає за технічних прогрес. 
- Капіталомісткість, або як іiі ще називають капіталоозброєність $\mathrm{k}=\mathrm{K} / \mathrm{L}$ (де K - обсяг капітальних ресурсів, L - кількість праці) не $\epsilon$ константою, як у неокейнсіанських моделях, а змінюється в залежності від макроекономічної ситуації в країні.

- Ціна та товари, послуги та ресурси для моделі Солоу є гнучкою, тобто модель описує завідомо ринкову економіку, де ціна на товар не встановлена державою, або якимось відповідним органом, а формується завдяки рівності попиту на пропозиції.

- Темп зростання праці, або трудових ресурсів дорівнює середньому темпу зростання населення. Проте не враховано ціну за працю, тобто середню заробітну плату, яка є динамічною, а саме при зростанні економіки - збільшується. При побудові моделі виноситься гіпотеза, що зростання населення та технічних прогрес відсутній на початковому етапі.

- Останньою передумовою $є$ те, що показники норми заощадження, амортизації, технічного прогресу, еластичності капіталу та праці, зростання населення є константами, а насправді кожен з цих показників є динамічним, тобто змінюється з плином часу [1;2].

Після усіх перетворень та врахувань, модель Солоу набуває вигляду:

$$
k^{\bullet}=s A k^{\alpha}-(d+n) k, \quad k_{0}=k\left(t_{0}\right),
$$

де змінна $k=k(t)$ відповідає капіталомісткості, $k^{\bullet}=\frac{d k}{d t}-$ перша $і 1 \mathrm{i}$ похідна; коефіцієнт $s$ - норма накопичування капіталу; константи $A$ та $\alpha$ належать функції Кобба-Дугласа економіки суспільства, відповідно $A$ відображає непрямі витрати, а величина $\alpha \epsilon$ еластичністю; коефіці$\epsilon$ нт, $s$ - норма накопичення капіталу, $d$ - ступінь вибуття капіталу, $n-$ середній темп зростання зайнятого населення, причому $d+n=\lambda$. [1;2].

Розглянемо, що ж забезпечує подальше зростання у моделі Солоу при досягненні стаціонарного стану економіки. Якщо заощадження перевищують обсяг інвестицій, яких потребує економіка - пропозиція стає вищою за попит і в результаті цього відбувається здешевлення фактору виробництва, який $є$ надмірним. Розглядаючи фактори виробництва з рівняння Кобба-Дугласа, надмірність капіталу призводить до переходу до більш капіталомістких технологій, а саме до технологічного прогресу. Динамічна рівновага $є$ стійкою, тому що зміна цін на фактори виробництва буде мотивувати економіку рухатися до стану стійної капіталомісткості, коли $\Delta \mathrm{k}=0[1 ; 2]$. 
Збільшення норми накопичення s призводить до підвищення рівноважного рівня капіталомісткості. Отож, можна зробити висновок про те, що більш висока норма накопичення призводить до більшого випуску валової продукції на душу населення. Зростання населення $\mathrm{n}$ призводить до більшої потреби у робочих місцях та обсягів товарів і послуг, а тому призводить до кількісного зростання обсягів попиту, і як результат ропозиції. Вибуття капіталу d зазвичай тільки гальмує економічний ріст і є більше індикатором рівня зношеності основних фондів підприємств у економічній системі, аніж на щось кардинально впливає.

У моделі Солоу технічний прогрес характеризується нейтральним видом, тобто коли при зростанні капіталомісткості економіки гранична корисність капіталу не знижується. Причина у тому, що таких технічний прогрес збільшує кількість зайнятих у тому ж темпі, яким зростає капітал. Дія такого типу технічного прогресу на економічне зростання пов'язано 3 приростом ефективності праці, за постійного темпу g. Тому показник g i відображає темп економічного прогресу. Враховуючи це, темп приросту 3 урахуванням технічного прогресу буде становити $\mathrm{n}+\delta+\mathrm{g}[1 ; 2]$.

Тож, модель Солоу показує, що в довгостроковому періоді постійний економічний ріст може забезпечити тільки рівень технологічного прогресу. Саме даний фактор може підтримувати неперервне зростання виробництва, а тому і зростання добробуту населення.

Модель Рамсея-Касса-Купманса. Основна ідея моделі полягає у тому, що норма заощаджень та темпи економічного зростання не задаються ззовні, а є результатом дій економічних контрагентів. Модель Рамсея-Касса-Купманса зберегла усі основні гіпотези моделі Солоу відносно виробничої функції. Норма заощадження у моделі Рамсея-Касса-Купманса перетворена на функцію корисності споживача. Функція корисності в моделі Рамсея-Касса-Купманса має вигляд:

$$
U=\int_{0}^{\infty} u(c t) e^{-(p-n) t} d t
$$

де $c t$ - споживання в момент часу $t$ на душу населення, $p$ - коефіцієнт переваги споживача, який $є$ константою та більший 0. Головним здобутком моделі Рамсея-Касса-Купманса є формування норми заощадження через вибір споживачів. Проблемою моделі $є$ споживач, який має сталі переваги впродовж свого життя і не враховується цикл життя споживача [3]. 
Модель Даймонда-Самуельсона. Дана проблема була вирішена Полом Самуельсоном, який є одним 3 авторів моделі перетинаючих поколінь. Модель перетинаючих поколінь, або модель Даймонда-Самуельсона є розвитком моделі Рамсея-Касса-Купманса. Основною відмінністю даної моделі $є$ те, що вона враховує цикл життя споживача і ділить його на два періоди: молодість та старість. Споживач розділяє отриману заробітну плату в молодості між молодістю та старістю і формує нову функцію корисності:

$$
U=\frac{c_{1 t}^{1-\theta}}{1-\theta}+\frac{1}{1+p} * \frac{c_{2 t+1}^{1-\theta}-1}{1-\theta},
$$

де $c_{1 t}$ - споживання в молодості, а $c_{2 t}$ - споживання в старості. В моделі стає можливим надмірне накопичення капіталу, що робить ii реалістичнішою, але тільки для розвинених країн, адже для країн, що розвиваються не характерне надмірне накопичення капіталу [4].

Модель Менк’ю-Ромера-Вейла. За моделлю Солоу нереалістично бути оцінені відсоткові ставки, тому у моделі Менк'ю-Ромера-Вейла було введено поняття людського капіталу, а функція Кобба-Дугласа, яка тут є основою набула вигляду:

$$
Y(K, H, L)=K^{\alpha} H^{\beta} L^{1-\alpha-\beta}
$$

де $H$ - людський капітал.

Неокласичні моделі пояснюють основні закономірності економічного зростання через темпи технологічного прогресу, який задається екзогенно, тобто ззовні. На відміну від неокласичних моделей економічного зростання, в ендогенних моделях технологічний прогрес $є$ наслідком рішень економічних агентів [5].

Модель Лукаса. Одним з перших, хто намагався додати до моделі економічного зростання ендогенну змінну є Р. Лукас, який досліджував запас людського капіталу та його ефективність. Згідно його праць, виробнича функція приймає наступний вигляд:

$$
Y_{t}=K_{t}^{1-\alpha}\left[u h_{t} L_{t}\right]^{1-\alpha} h_{\alpha \cdot t}^{\delta},
$$

де $\mathrm{u}$ - частка витрат праці на людський капітал; $\mathrm{h}_{\mathrm{t}}$ - запас людського капіталу; $\mathrm{h}_{\alpha \mathrm{t}}-$ середній рівень людського капіталу в економіці на період часу $\mathrm{t}$ [6]. 
Модель Ромера. Модель базується на наступних передумовах:

- важливим чинником економічного зростання $є$ технологічний прогрес, який збільшує ефективність поєднань інших виробничих ресурсів;

- технологічні зміни відбуваються завдяки діяльності людини, яка подібним чином реагує на ринкові зміни;

- технологічний прогрес виражається у створенні певних інструкції використання виробничих ресурсів;

- інструкції з використання сировинних матеріалів відрізняються від інших економічних виробничих факторів: витрати на створення нових інструкцій є постійними витратами виробництва, а використання старих інструкцій не потребує додаткових витрат.

Модель Ромера вказує на джерела наукових знань, для яких є характерним вплив на виробничу сферу країни та на сферу послуг. Якщо країна не витрачає достатньо коштів на створення нових знань та на технологічний прогрес, то вона у довгостроковому періоді не може розраховувати на високі темпи економічного розвитку, а тільна на віддачу від масштабу виробництва [7].

Модель Агійона та Хоувітта. Згідно цієї моделі економічне зростання зумовлюється технічним прогресом на основі конкуренції між фірмами та підприємствами, які створюють технологічні нововведення. У результаті цих нововведень ринок поповнюється новими ефективнішими технологіями для швидшого та продуктивнішого виробництва кінцевої продукції.

Моделі економічного зростання з ендогенних технологічним прогресом також мають ряд недоліків. У моделях характер технологічного прогресу будується на не обгрунтованих та достатньо перевірених припущеннях, такими необгрунтованими припущеннями є природа технологічного прогресу, структура ринків, процеси формування людського капіталу тощо [8].

\section{3. Виведення математичної бази для оцінювання}

Проведемо інтегрування рівняння Солоу і отримаємо його аналітичний розв'язок:

$$
k(t) \leq\left[\left(k_{0}^{1-\alpha}-\frac{s(1-\alpha)}{\lambda}\right) e^{-\lambda t(1-\alpha)}+\frac{s A(1-\alpha) t}{\lambda}\right]^{\frac{1}{1-\alpha}}
$$


Від нелінійної динамічної моделі (1) перейдемо до нерівності:

$$
k^{\bullet} \leq s A k^{\alpha} .
$$

Таким чином, згідно виразу (8), потенціал економічного зростання буде залежати від норми накопичення капіталу, яка є основою інвестицій в закритій економіці, від показника технологічного прогресу, який відповідає за інтенсивний економічний ріст, та капіталомісткості виробництва. 3 ортодоксальної моделі економічного зростання Солоу виключено частину, яка відповідає за негативні явища, які зменшують темпи економічного зростання.

Амортизація капіталу показує зношеність основних фондів. При визначенні величини потенціалу економічного зростання, виносимо гіпотезу, що основні виробничі фонди країни $є$ новими і у хорошому технічному стані, тому величина амортизації буде дуже малою, щоб мати помітний вплив на кінцевий результат.

Показник $n$ відповідає за темпи зростання зайнятого населення. При зростанні населення, економіка потребує більше робочих місць, а тому капітал замінюється працею, i, як наслідок, зменшується капіталомісткість виробництва. Але, при розрахунку потенційного економічного зростання, беремо до уваги те, що для економіки віддача від одиниці капіталу набагато вища, ніж від одиниці праці. Тому вигідніше збільшувати обсяг капіталу, ніж обсяг праці, а тому коефіцієнт $n$ також виключаємо.

Інтегруючи вираз (2) отримуємо мажорантну оцінку:

$$
k(t) \leq\left[k_{0}^{1-\alpha}+s A(1-\alpha) t\right]^{\frac{1}{1-\alpha}} .
$$

Зауваження: маючи статистичні дані для економіки суспільства, розраховуються величини А та $\alpha$ за формулою:

$$
\ln \left(\frac{Y}{L}\right)=\ln (A)+\alpha \ln \left(\frac{K}{L}\right),
$$

3 використанням функції «linest» табличного процесора Excel, або функції «lm» мови програмування R. Вираз (10) також називають логарифмічною формою рівняння Кобба-Дугласа.

Отже, потенційна капіталомісткість є результатом вливання капіталу, через інвестиції та технологічний прогрес до початкового значення капіталомісткості. Оскільки технологічний прогрес та норма накопи- 
чення капіталу виражені коефіцієнтами, то їх сумарний вплив пояснюється порядковим періодом.

Усі відомі моделі економічного зростання, як неокласичні так і ендогенного зростання, вважають коефіцієнт еластичності капіталу сталим для економіки суспільства. Але дане припущення не зовсім вірне. Виходячи із визначення еластичності капіталу: при зростанні обсягу капіталу на 1 одиницю, його віддача зростає на $\alpha$ одиниць. За законом спадної граничної корисності: 3 кожною додатковою одиницею блага, його гранична корисність зменшується. Так і $з$ капіталом: при зростанні капіталу, його гранична віддача зменшуватиметься.

Технологічний прогрес діє зворотньо: при зростанні рівня технологій капітал використовується ефективніше, тож його віддача зростатиме.

Для початку запишемо другу похідну рівняння (2):

$$
k^{\bullet}=\left[s A \alpha k^{\alpha-1}-(d+n)\right] k^{\bullet} .
$$

Очевидним чином виконується:

$$
\frac{k^{\bullet \bullet}}{k^{\bullet}} k=\left[s A \alpha k^{\alpha-1}-(d+n)\right] k .
$$

Або:

$$
\frac{k^{\bullet \bullet}}{k^{\bullet}} k=\alpha\left[s A k^{\alpha}-\frac{(d+n)}{\alpha} k\right] .
$$

Отже, приблизно можна покласти:

$$
\frac{k^{\bullet \bullet}}{k^{\bullet}} k \simeq \alpha k^{\bullet}\langle=\rangle \frac{k^{\bullet \bullet}}{k^{\bullet}} \simeq \alpha \frac{k^{\bullet}}{k},
$$

тобто, відношення другої похідної $k^{*}$ до першої є добуток коефіцієнта еластичності на темп зростання. По-іншому, справедливим буде вираз:

$$
\alpha \simeq \frac{k^{\bullet \bullet}}{\left(k^{\bullet}\right)^{2}} k,
$$

який засвідчує наявність динамічної траєкторії еластичності, оскільки співмножники виразу є функції незалежної змінної $t$ [9].

Тож, як видно з формули (15), коефіцієнт еластичності капіталу залежить від самої капіталомісткості, швидкості зміни капіталомісткості та прискорення капіталомісткості.

Швидкість зміни величини капіталомісткості, або перша похідна капіталомісткості характеризує зменшення віддачі від зростання об- 
сягу капіталу, що в цілому уповільнює темпи економічного зростання. Друга похідна капіталомісткості $є$ прискоренням економічного зростання, а тому відповідає за технологічний прогрес, який є непостійною величиною.

Далі доведемо що темп економічного розвитку є спадною величиною для будь-якої економіки. Виходячи з того, що віддача від кожної додаткової одиниці капіталу зменшується, та 3 того, що для інновацій у довгостроковому періоді потрібно все більше коштів на розробку, а приносять вони все менше, то у довгостроковому періоді темп зростання економіки зменшується, оскільки дві основні рушійні сили зростання обсягу ВВП мають спадну тенденцію.

Розглянемо першу похідну величини оберненої до темпу:

$$
\left(\frac{k}{k^{\bullet}}\right)^{\prime}=\frac{k^{\bullet} k^{\bullet}-k^{\bullet \bullet} k}{\left(k^{\bullet}\right)^{2}} \equiv\left(1-\frac{k k^{\bullet \bullet}}{k^{\bullet} k^{\bullet}}\right) .
$$

3 огляду на вираз (8) остаточно записується:

$$
\left(\frac{k}{k^{*}}\right)^{\prime}=(1-\alpha) \text {. }
$$

Інтегруванням останнього виразу знаходимо:

$$
\frac{k^{\bullet}}{k}=\frac{1}{(1-\alpha) t},
$$

тобто, з плином часу темп падає, що цілком відповідає наявним уявленням з інших позицій.

Стаціонарна точка $k^{\bullet}\left(k^{\bullet}=0\right.$, де $k^{\bullet}-$ похідна $k$ ) траєкторії економічного розвитку розраховується за формулою:

$$
k^{*}=\left[\frac{d+n}{s A}\right]^{\frac{1}{1-\alpha}} .
$$

Стаціонарна точка показуватиме рівень капіталомісткості виробництва, при якому подальше зростання економіки буде можливе лише за рахунок науково-технічного прогресу [9].

\section{4. Результати дослідження}

У таблиці 1 представлено десятка кращих країн світу за розміром потенційного ВВП у 2019 році. 


\section{Таблиця 1}

Топ-10 країн світу за розміром потенційного ВВП у 2019 році

\begin{tabular}{|l|c|c|c|}
\hline \multicolumn{1}{|c|}{ Краӥна } & $\begin{array}{c}\text { Потенційний ВВП } \\
\mathbf{2 0 1 9}\end{array}$ & Реальний ВВП 2019 & $\begin{array}{c}\text { \% вико- } \\
\text { ристання }\end{array}$ \\
\hline Сполучені Штати & 1120433248852050,00 & 19331219192300,00 & $2 \%$ \\
\hline Франція & 187839134513478,00 & 3073690088231,00 & $2 \%$ \\
\hline Великобританія & 178533836823668,00 & 2976281197034,77 & $2 \%$ \\
\hline Канада & 121494790568366,00 & 2009508381668,89 & $2 \%$ \\
\hline Бельгія & 94704252416247,60 & 555892566917,86 & $1 \%$ \\
\hline Австралія & 87221962312271,60 & 1540200343702,84 & $2 \%$ \\
\hline ОАЕ & 77679719293830,70 & 409315180394,83 & $1 \%$ \\
\hline Китай & 71769754303360,00 & 12806677717792,70 & $18 \%$ \\
\hline Швейцарія & 44490940953918,70 & 721131480088,05 & $2 \%$ \\
\hline Швеція & 34727519530778,40 & 623097849101,91 & $2 \%$ \\
\hline
\end{tabular}

За абсолютним значенням потенційного ВВП беззаперечним лідером є США, а за ним йдуть Франція, Великобританія, Канада, Бельгія, Австралія, ОАЕ, Швейцарія, Швеція та Німеччина. Ці країни є лідерами на міжнародній арені та розвиваються завдяки технологічному прогресі. США займає 46\% серед усього потенційного ВВП, а країни топ-10 - 85\% (рис. 1). Країни Африки та Океанії традиційно пасуть задніх через низький рівень технологічного розвитку та малу кількість природних мінеральних ресурсів.

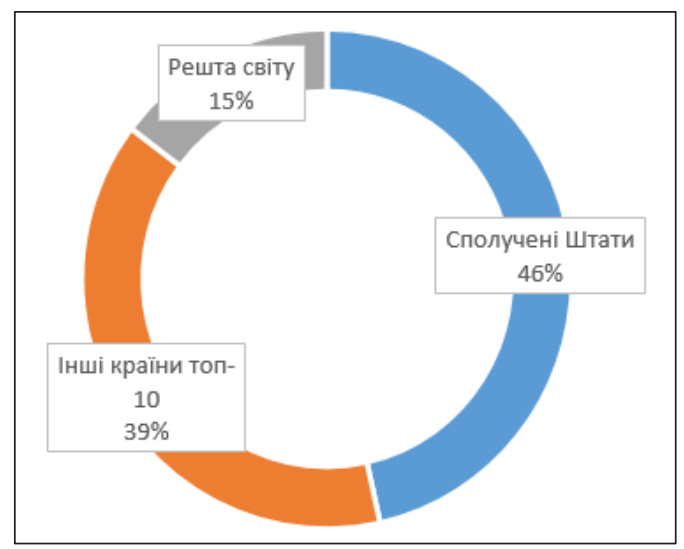

Рис. 1. Розподіл потенційного ВВП по країнам світу 
Лідерами за сумою потенційного ВВП є Північна Америка, завдяки США та Канаді, та Європа, завдяки Німеччині, Франції, Великобританії та іншим країнам з топ-10. Тому економічне районування на найближчі роки за модифікованою моделлю Солоу залишається незмінним, економічними центрами залишаються ЄС та США.

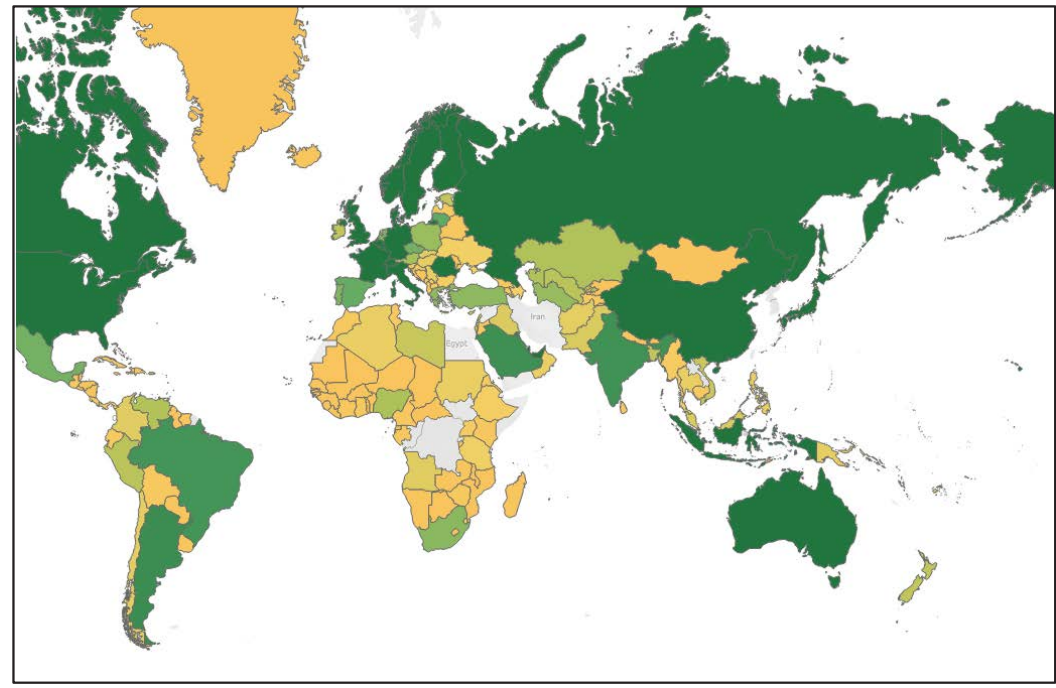

\section{Рис. 2. Розмір потенційного ВВП}

Показник потенційного ВВП на душу населення більш наглядно показує ефективність та організацію економічного управління, адже виключає ефект від масштабу країни. У таблиці 2 представлено десятка кращих країн світу за розміром потенційного ВВП на особу у 2019 році.

Лідерами по обсягу ВВП на особу є Люксембург, Бельгія, ОАЕ, Катар та Монако, у більшій мірі через невелику кількість населення та джерело доходів, яке становить значну долю від ВВП. Україна знаходиться на 139 місці, що є дуже низьким показником у більшій мірі через недостатність капіталу в економіці, через що економіка не може розвиватися швидкими темпами. Останніми є країни Африки через високі темпи зростання населення, низький рівень технологічного прогресу та малий показник капіталу. 
Таблиця 2

Топ-10 країн світу за розміром потенційного ВВП на особу у 2019 році

\begin{tabular}{|c|l|c|c|c|}
\hline № & \multicolumn{1}{|c|}{ Країна } & $\begin{array}{c}\text { Реальний ВВП } \\
\text { на особу 2019 }\end{array}$ & $\begin{array}{c}\text { Потенційний } \\
\text { ВВП на особу } \\
\mathbf{2 0 1 9}\end{array}$ & $\begin{array}{c}\text { \% } \\
\text { використання }\end{array}$ \\
\hline 1 & Люксембург & 112218,77 & 19900635,28 & $1 \%$ \\
\hline 2 & Бельгія & 48496,08 & 8262000,29 & $1 \%$ \\
\hline 3 & ОАЕ & 42025,66 & 7975617,94 & $1 \%$ \\
\hline 4 & Катар & 63973,12 & 7577632,71 & $1 \%$ \\
\hline 5 & Монако & 155884,63 & 6446975,52 & $2 \%$ \\
\hline 6 & Норвегія & 95209,24 & 5169422,50 & $2 \%$ \\
\hline 7 & Швейцарія & 83766,35 & 5168050,55 & $2 \%$ \\
\hline 8 & Данія & 65235,66 & 4613651,96 & $1 \%$ \\
\hline 9 & Сан-Марино & 55935,69 & 4294594,46 & $1 \%$ \\
\hline 10 & Андорра & 47078,42 & 4113685,07 & $1 \%$ \\
\hline
\end{tabular}

У 2039 році загальний світовий ВВП становитиме 3574914352661 350,00 дол. До 2039 року США успішно утримує лідерство по обсягу ВВП у світі і займатиме частку у 48\%. У десятку кращих входять також Франція, Великобританія, Канада, Австралія,

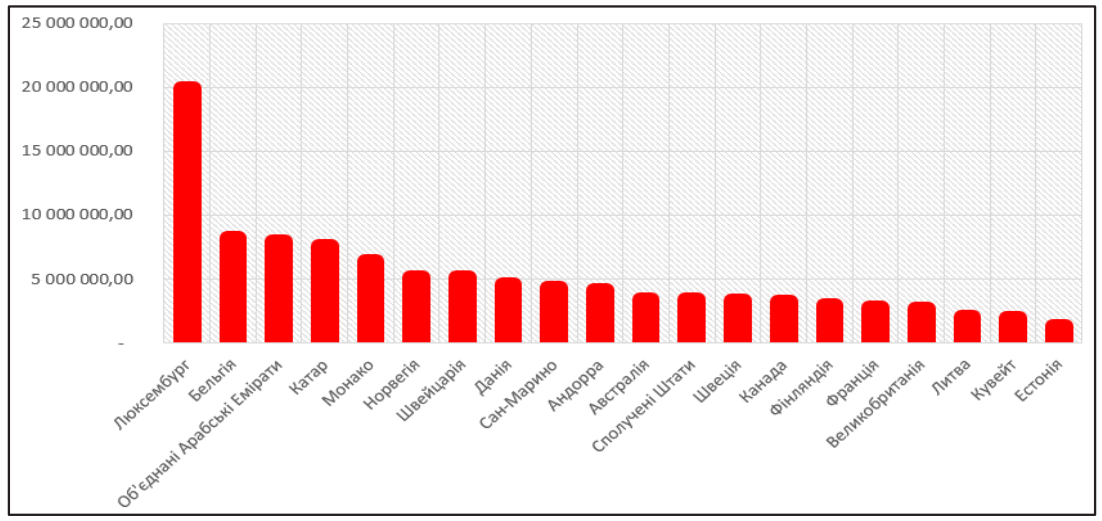

Рис. 3. Двадцять кращих країн за потенційним ВВП на особу у 2019 році 


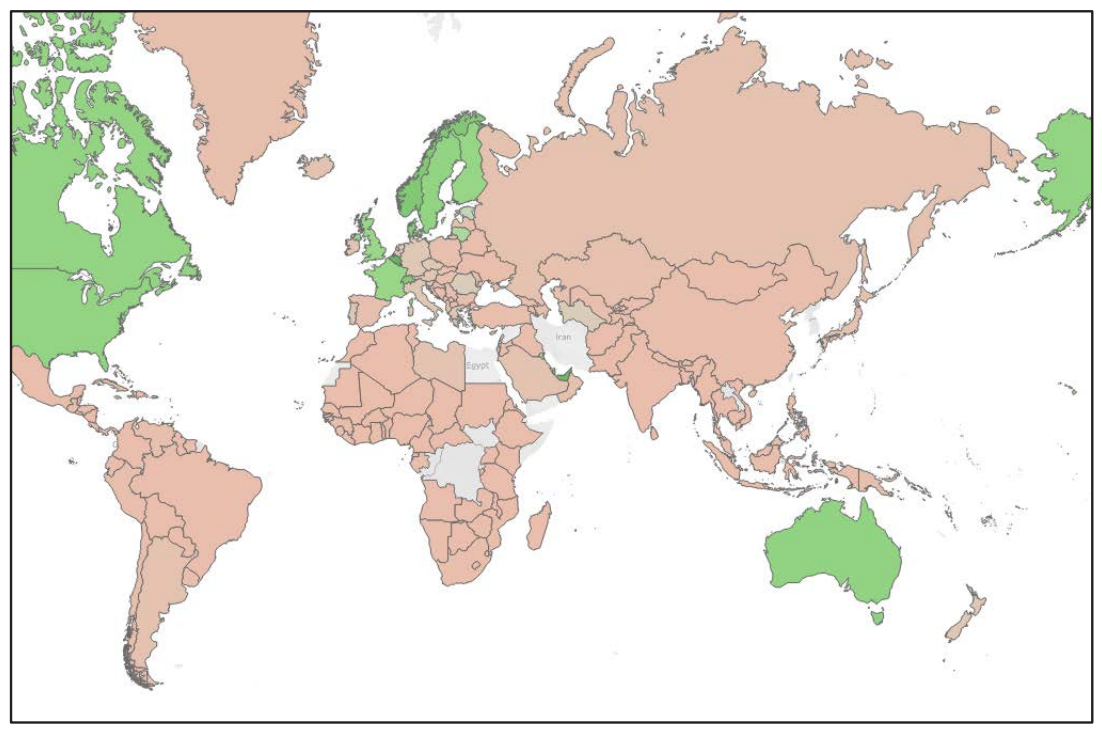

Рис. 4. Потенційний ВВП на особу у 2019 році

OAE, Китай, Бельгія, Швейцарія та Швеція. Україна $з$ показником 562203660 942,96 дол. ВВП знаходиться на 79 місці у світі та використовує свій потенціал на $36 \%$. Останні країни у списку - це острівні країни Карибського моря та Океанії. Кілька країн до 2039 року перевищать показники свого потенційного ВВП, серед таких країн: Мальта (682\%), Марокко (426\%), Сінгапур (370\%), Таїланд (251\%), Гонконг $(208 \%)$, Туреччина (190\%), Бутан (163\%), Гренада (145\%), Гренландія (112\%), Туніс (110\%). Більшість країн малі за розміром, окрім Гренландії, але вона населення у цій країні становить лише 76 тис. осіб, і країна є автономією Данії.

Найкраще використали потенціал такі країни як Бутан (78\%), Монголія (74\%), Гренада (72\%) та Мальта (71\%). Бутан - це гірська країна в Гімалаях, що не має багатих ні мінеральних, ні трудових ресурсів, а тому початковому капіталу дуже важко розвинутися. Монголія має населення всього 3 млн осіб, що дуже мало для такої території, як у цієї країни, а тому нікому використовувати природні ресурси країни, які і без того дуже бідні, а більшість країни займає пустеля. Мальта 
Chapter «Economic sciences»

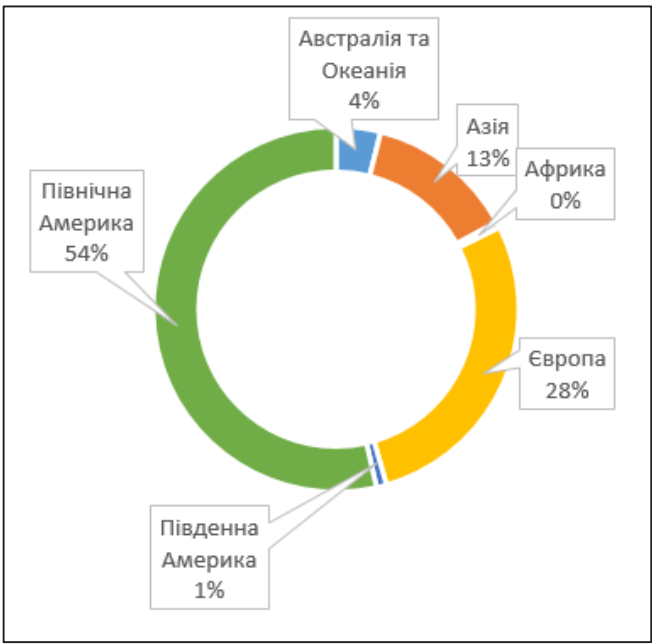

Рис. 5. Прогнозні значення потенційного ВВП у 2039 році

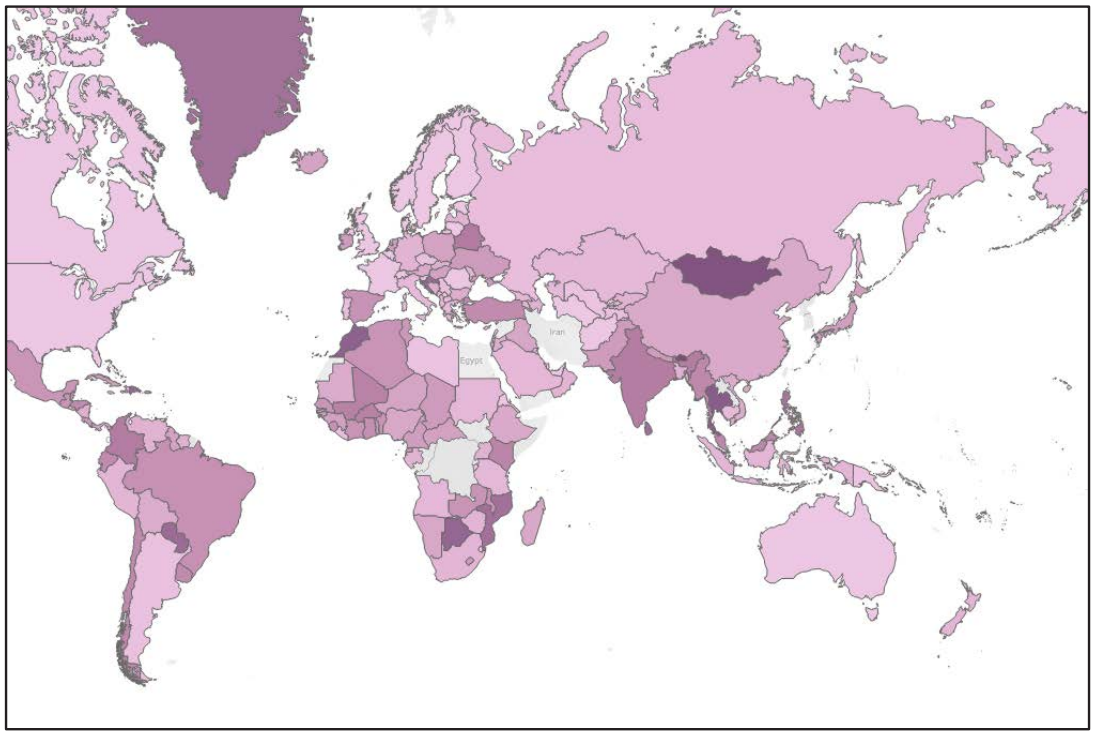

Рис. 6. Значення усередненого коефіцієнта використання потенціалу 
реалізувала свій потенціал добре завдяки вступу в СС та користуванням вигоди від цього. Гренада - мала країна у Карибському морі, основним заробітком якої є рекреаційні ресурси. Ситуація серед країн Великої сімки: США, Франція, Великобританія, Канада (2\%), Японія (24\%), Німеччина (12\%), Італія (9\%). Україна має коефіцієнт реалізації економічного потенціалу - 26\%, Польща - 22\%. Отже, на коефіцієнт реалізації потенціалу впливають: капітал, трудові ресурси, рівень науково технічного прогресу тощо. Так, Японія має таке високе значення через недостатність власних мінеральних ресурсів, Німеччина через глибоку економічну кризу 1950-1965-х років, Італія не має дуже потужної економіки та має багато соціально-економічних проблем. Так, США, Франція, Великобританія та Канада не мають у своїй історії розглянутого періоду якихось значних кризових явищ та забезпечені в достатній кількості капітальними і трудовими ресурсами, тож і мають високий економічний потенціал.

\section{5. Висновки}

Теоретична та методична значущість роботи полягає у описі принципового нового методу моделювання, за допомогою якого можна оцінити потенціал економічного розвитку, доведення динамічності коефіцієнтів еластичності виробничих факторів, та доведення гіпотези про спадний темп економічного зростання. Розроблена модель ефективно оцінює потенціал економічного росту для будь-якої країни і може бути використана як база для прогнозу показників потенційної капіталомісткості виробництва та потенційного валового внутрішнього продукту. Практична значущість отриманих результатів, підкріплена реальними даними та є наслідком економічних, політичних чи соціальних явищ в економіці країни, яка розглядалася. У подальшому дослідженні можна розвивати дану модель, додаючи до неї нові змінні, які впливають на економічне зростання, оновлювати методологію знаходження коефіцієнтів як результату дій економічних агентів, а не лише їх екзогенних вплив на економіку.

Подальше дослідження дасть змогу точніше прогнозувати глобальну економічну ситуацію у світі, визначати потенційних економічних лідерів та оцінювати швидкість зростання економіки для будь-якої країни світу з урахуванням більшої кількості змінних. 


\section{Список літератури:}

1. Solow R. M. (1956) A Contribution to the Theory of Economic Growth. The Quarterly Journal of Economics. Vol. 70. № 1: 65-94.

2. Solow R. M. (1957) Technical Change and the Aggregate Production Function. The Review of Economics and Statistics. Vol. 39. № 3: 312-320.

3. Koopmans T. C. (1963) On the concept of optimal economic growth. Cowles Foundation for Research in Economics, Yale University, Discussion Paper. № 163.

4. Diamond P. A. (1965) National Debt in Neoclassical Growth Model. The American Economic Review. Vol. 55. № 5: 1126-1150.

5. Mankiw G., Romer D., Weil D. (1992) Contribution to the Empirics of Economic Growth. The Quarterly Journal of Economics. Vol. 107. № 2: 407-437.

6. Lucas R. E. (1988) On the mechanics of economic development. Journal of Monetary Economics. Vol. 22. № 1: 3-42.

7. Romer P. M. (1989) Human Capital And Growth: Theory and Evidence. NBER Working paper. № 3173.

8. Aghion P. M., Howitt P. W. (1990) A Model of Growth Through Creative De-struction. NBER Working Paper. № 3223.

9. Kolyada Yu. V., Poznyak S. P. (2019) Estimation of evolutionary economy in one dimensional case. International scientific-practical conference Endless Light in Science.

\section{References:}

1. Solow R. M. (1956) A Contribution to the Theory of Economic Growth. The Quarterly Journal of Economics, vol. 70, no. 1: 65-94.

2. Solow R. M. (1957) Technical Change and the Aggregate Production Function. The Review of Economics and Statistics, vol. 39, no. 3: 312-320.

3. Koopmans T. C. (1963) On the concept of optimal economic growth. Cowles Foundation for Research in Economics, Yale University, Discussion Paper, no. 163.

4. Diamond P. A. (1965) National Debt in Neoclassical Growth Model. The American Economic Review, vol. 55, no. 5: 1126-1150.

5. Mankiw G., Romer D., Weil D. (1992) Contribution to the Empirics of Economic Growth. The Quarterly Journal of Economics, vol. 107, no. 2: 407-437.

6. Lucas R. E. (1988) On the mechanics of economic development. Journal of Monetary Economics, vol. 22, no. 1: 3-42.

7. Romer P. M. (1989) Human Capital And Growth: Theory and Evidence. NBER Working paper, no. 3173.

8. Aghion P. M., Howitt P. W. (1990) A Model of Growth Through Creative De-struction. NBER Working Paper, no. 3223.

9. Kolyada Yu. V., Poznyak S. P. (2019) Estimation of evolutionary economy in one dimensional case. International scientific-practical conference Endless Light in Science. 